\title{
PERAN ORANG TUA DAN GURU DALAM PEMBELAJARAN DARING DI TK SATAP INPRES 1 BALUASE KECAMATAN DOLO SELATAN KABUPATEN SIGI
}

\author{
Sri Alfianti ${ }^{1)}$ Ahmad Syahid ${ }^{2)}$ M. Iksan Kahar ${ }^{3)}$ \\ ${ }^{1}$ Mahasiswa Program Studi PIAUD FTIK Institut Agama Islam Negeri Palu \\ ${ }^{2}$ Dosen Fakultas Tarbiyah dan Ilmu Keguruan Institut Agama Islam Negeri Palu \\ ${ }^{3}$ Dosen Fakultas Tarbiyah dan Ilmu Keguruan Institut Agama Islam Negeri Palu
}

\begin{abstract}
ABSTRAK
Penelitian ini membahasa tentang peran orang tua dan guru terhadap anak pada pembelajaran daring di TK Satap Inpres 1 Baluase Kecamatan Dolo Selatan Kabupaten Sigi. Penelitian ini menggunakan pendekatan kualitatif. Teknik pengumpulan data melalui observasi, wawancara dan dokumentasi. Teknik analisis data yang digunakan adalah reduksi data, penyajian data dan verifikasi data. Berdasarkan hasil penelitian, diperoleh bahwa peran orang tua dan guru terhadap anak pada pembelajaran daring di TK Satap Inpres 1 Baluase Kecamatan Dolo Selatan Kabupaten Sigi tidak lepas dari peran dan tanggung jawab orang tua apalagi pada masa pandemi saat ini yang mengharuskan anak untuk belajar di rumah dengan didampingi oleh orang tua. Selain orang tua, guru juga sangat berperan penting dalam melakukan upaya tertentu agar pembelajaran daring dapat bermanfaat dan tentunya menyenangkan, guru juga harus menciptakan suasana belajar jadi lebih menyenangkan bagi anak didik agar anak tidak mudah bosan. Pembelajaran daring dapat berjalan dengan lancar, bermakna, serta tercapai hasil belajar yang baik harus didukung oleh kemampuan guru terhadap penguasaan komputer dan internet.
\end{abstract}

Kata Kunci : Orang Tua dan Guru, Pembelajaran Daring.

\section{PENDAHULUAN}

Covid-19 merupakan virus yang terindikasi sebagai pengembangan virus yang intensitasnya mengalami perubahan signifikan sehingga tergolong sebagai virus baru. Virus ini memberikan dampak yang sangat luar biasa sampai menginfeksi nyaris 100 ribu orang setiap harinya. Pandemi yang berawal dari Wuhan, Tiongkok ini sudah merambah ke 212 negara, sehingga seluruh aktifitas dihentikan termasuk anak-anak sekolah harus belajar di rumah. Pendidikan daring menjadi pelengkap pembelajaran dengan mengerahkan peran orang tua, peran guru dan peran anak dalam menghadapi virus Covid-19. ${ }^{1}$

${ }^{1}$ Afrillia Fahrina dan Karla Amelia dkk, Peran Guru dan Keberlangsungan Pembelajaran di Masa Pandemi Covid-19, (Cet.1; Aceh; Syiah Kuala University Press, 2020),67-73 
Awal mula saat anak-anak sudah mulai tidak berangkat sekolah orang tua menjadi guru bagi anak-anak menggantikan peran tenaga pendidik di sekolah saat mengikuti anjuran pemerintah untuk tetap berada di rumah akibat virus Corona (Covid-19). Peran orang tua menghadapi era Covid-19 ini sangat penting, pada saat anak mendapatkan materi pelajaran melalui aplikasi WA (WhatsApp) dari guru tugas orang tua adalah memberikan pengarahan dan membimbing bagaimana agar anak dapat mencerna dan mengimplementasikan materi tersebut dengan benar. ${ }^{2}$

Peran orang tua sangat diperlukan untuk proses pembelajaran anak selama pembelajaran daring saat ini. Dengan peran yang aktif juga akan memberikan pemahaman kepada anak-anaknya tentang protokol kesehatan selama pandemi agar tidak tertular dan menularkan. Pembelajaran di rumah dinilai tetap mampu meningkatkan kualitas pembelajaran begitupun dengan pembelajaran di sekolah. Kebijakan pembelajaran di rumah dapat dikatakan banyak hikmahnya, dikarenakan pola hubungan antara anak dan orang tua bisa lebih terjalin dan orang tua bisa lebih mengawasi anak-anaknya dalam proses pembelajaran yang dilakukan secara daring di rumah. $^{3}$ Dengan demikian peran orang tua merupakan cara yang digunakan oleh orang tua berkaitan dengan pandangan mengenai tugas yang harus dijalankan dalam mengasuh anak. Memiliki kewajiban dan bertanggung jawab untuk mengasuh, memelihara, mendidik, dan melindungi anak.

Proses pembelajaran untuk anak usia dini selama masa pandemi covid-19 ini dilakukan dari rumah dengan menuntut peran serta orang tua. Guru memberikan informasi kepada orang tua baik itu melalui media whatsapp group maupun berupa worksheet yang dibagikan oleh guru kepada orang tua. Selain itu, terdapat pula guru yang menerapkan pola seperti halnya konsep merdeka belajar, di mana anak diberikan kebebasan dalam melakukan kegiaan belajar di rumah bersama orang tua. Dalam hal ini, orang tua dituntut untuk melaporkan hasil kegiatan anak melalui foto, video, maupun penyetoran hasil pekerjaan anak melalui worksheet yang dibagikan oleh guru. Hasil laporan orang tua mengenai kegiatan anak selama belajar dari rumah menjadi cerminan bagi guru untuk melakukan penilaian perkembangan anak, yang pada akhirnya menjadi laporan perkembangan anak. ${ }^{4}$ Dengan demikian pembelajaran anak usia dini saat pandemi guru diharapkan mampu menjaga komunikasi dua arah dengan orang tua dan anak didik secara regular. Diawali dengan memastikan kebutuhan dasar anak terpenuhi, kemudian dilanjutkan dengan berbagi ilmu kiat-kiat mendidik anak sesuai metode pembiasaan di PIAUD.

\footnotetext{
${ }^{2}$ Ibid, 70

${ }^{3}$ Andi Muhammad Lutfi dan Akhmad Arianto dkk, Media Daring (Online) Solusi Pembelajaran Jarak Jauh, (Cet.1; Parepare; IAIN Parepare Nusantara Press, 2020), 8 2020), 93

${ }^{4}$ Ida Bagus dan Benny Surya, Adaptasi di Masa Pandemi, (Cet.1; Bandung; Nilacakra;
} 
Pendidikan Islam Anak Usia Dini (PIAUD) merupakan bentuk penyelenggaraan pendidikan yang ditunjukkan kepada anak yang berusia 0-6 tahun untuk membantu anak melewati tugas-tugas perkembangannya dan mempersiapkan anak untuk mengikuti jenjang pendidikan selanjutnya. Dalam dunia pendidikan, termasuk PIAUD terdapat tri pusat pendidikan yang berperan penting dalam pelaksanaannya. Istilah tri pusat pendidikan ini dicetuskan oleh tokoh pendidikan Indonesia, yaitu Ki Hajar Dewantara. Tri pusat pendidikan tersebut adalah "keluarga, sekolah, dan masyarakat. Ketiga lingkungan tersebut saling bersinergi dalam memberikan rangsangan pendidikan kepada anak usia dini". 5

TK Satap Inpres 1 Baluase adalah salah satu sekolah PAUD yang ada di Desa Baluase Kecamatan Dolo Selatan Kabupaten Sigi. Penulis memilih lokasi ini karena melihat kurangnya pemahaman orang tua terhadap sistem pembelajaran yang dilakukan secara daring dan bagaimana guru mengimplementasikan media pembelajaran melalui daring di TK Satap Inpres 1 Baluase. Penulis ingin mengetahui bagaimana peran orang tua dan guru dalam mendampingi dan mendukung proses belajar anak di rumah. Dalam pembelajaran berbasis daring, guru juga dituntut harus lebih kreatif dalam memberikan pembelajaran pada anak agar anak tidak merasa bosan pada saat pembelajaran berlangsung. Namun meskipun anak di dampingi orang tua pada saat mengikuti pembelajaran, hal itu tidak menutup kemungkinan bahwa banyak anak yang belum mengerti tentang apa yang di berikan guru pada mereka.

\section{METODE PENELITIAN}

Jenis penelitian yang digunakan dalam penelitian ini adalah penelitian kualitatif. Lokasi penelitian yakni di TK Satap Inpres 1 Baluase Kecamatan Dolo Selatan Kabupaten Sigi. Adapun sumber data atau informan penelitian ini adalah Kepala TK Satap Inpres 1 Baluase, Guru TK Satap Inpres 1 Baluase, orang tua, dan anak didik.

Teknik pengumpulan data yang digunakan adalah teknik observasi, dokumentasi dan wawancara. Adapun teknik analisis data yang dilakukan meliputi reduksi data, penyajian data dan verifikasi data. Data-data yang telah didapatkan dari lokasi penelitian sangat penting untuk dicek kembali, agar benarbenar memperoleh data yang akurat sesuai harapan. Empat kriteria yang menunjukkan keabsahan suatu data, yang menurut Lexy J. Moelong adalah 'derajat kepercayaan (credibility), keteralihan (transferability), ketergantungan (dependability) dan kepastian (konfirmality). ${ }^{6}$ Selanjutnya, untuk mengecek keabsahan data yang diperoleh maka dilakukan tehnik pemeriksaan atau pengecekan data yang memanfaatkan sesuatu yang lain, diluar data itu untuk

${ }^{5}$ I Ketut Sudarsana dkk, COVID-19: Perspektif Pendidikan, (Cet.1; Denpasar; Yayasan Kita Menulis, 2020), 11

${ }^{6}$ Lexy J. Moleong, Metodologi Penelitian Kualitatif (Bandung : Rosdakarya), 115 
keperluan pengecekan dan perbandingan. Menurut sugiyono, Tiga macam triangulasi sebagai tehnik pemeriksaan yaitu "triangulasi dengan sumber, triangulasi dengan tehnik pengumpulan data, triangulasi waktu. ${ }^{7}$

\section{HASIL DAN PEMBAHASAN}

\section{A. Proses Pembelajaran Daring di TK Satap Inpres 1 Baluase}

Proses pembelajaran mencakup penggunaan metode-metode pengajaran dan kegiatan-kegiatan pembelajaran yang bertujuan menolong anak didik menguasai materi pembelajaran dan mencapai tujuan pembelajaran yang sudah ditetapkan dalam kurikulum dan untuk pelaksanaan kegiatan pembelajaran tentu menggunakan perencanaan dan dalam melaksanakan tugas pembelajaran, setiap guru pasti mengawalinya dari perencanaan. Sedangkan sebuah perencanaan harus berpedoman pada rambu-rambu pendidikan, seperti rencana pelaksanaan pembelajaran harian $(\mathrm{RPPH})$. Oleh sebab itu, setiap tugas yang disiapkan guru harus mengacu pada pedoman yang ada.

Pada jenjang PIAUD kegiatan dapat dilakukan dalam bentuk bermain kegiatan lebih banyak menekankan pada aktivitas anak. Pembelajaran pada anak usia dini harus dilakukan dengan menarik, menyenangkan, penuh dengan permainan dan keceriaan. Tentunya hal ini membutuhkan dukungan dari lingkungan dan ketersediaan alat pembelajaran apalagi dalam kondisi saat ini pandemi covid-19 sangat berdampak pada proses pembalajaran khususnya pendidikan anak usia dini yang mengharuskan anak didik belajar dari rumah.

Dalam proses pembelajaran yang dilakukan guru di masa pandemi diilakukan dengan cara pembelajaran jarak jauh (daring), proses perencanaa yang sedari awal itu dilakukan secara langsung atau tatap muka semua di ubah menjadi pembalajaran daring. Dengan demikian TK Satap Inpres 1 Baluase menerapkan satu sistem pembelajaran daring yang dimana anak didik harus belajar di rumah dengan dibantu oleh orang tua agar menghindari terjadinya penyebaran virus covid-19.

Upaya yang dilakukan kepala TK Satap Inpres 1 Baluase agar anak didik tidak tertinggal dalam pembelajaran, maka dilakukan sistem pembelajaran berbasis daring di masa pandemi covid-19, sebagaimana dijelaskan kepala TK Satap Inpres 1 Baluase dalam wawancaranya sebagai berikut:

Sebenarnya ada dua sistem pembelajaran yang kami terapkan di TK yaitu sistem pembelajaran daring dan luring. Dalam pembelajaran daring guru mengajar dengan menggunakan rekaman video kemudian di kirim kepada orang tua anak, dalam sistem pembelajaran daring ini anak-anak hanya

${ }^{7}$ Sugiyono, Metode Penelitian Pendidikan Pendekatan Kuantitaf, Kualitatif Dan R\&D (Cet.XX;Bandung: Alfabet, 2014), 179. 
diberikan tugas saja kemudian dipraktekkan dan dikirim kembali kepada guru kelas. $^{8}$

Pembelajaran berbasis daring ini dilakukan seminggu sekali hal ini disebabkan keterbatasan orang tua anak didik yang belum semuanya mempunyai Hp android, bagi orang tua yang tidak memiliki Hp android maka guru melakukan kunjungan ke rumah orang tua anak didik. Berikut ini penuturan ibu Andia orang tua dari Lestari tentang masalah di atas mengenai proses pembelajaran daring yang diterapkan di TK Satap Inpres 1 Baluase:

Proses pembelajaran yang diterapkan di TK Satap Inpres 1 Baluase selama pandemi adalah sistem pembelajaran daring yang dimana kegiatan pembelajaranya dilaksanakan dari rumah dan sangat membutuhkan pendampingan dari orang tua. Saya mendampingi dan membantu anak saya belajar ketika malam hari karena pada siang hari saya harus bekerja. Pembelajaran daring ini juga sangat mudah dilakukan di rumah karena ibu guru mengirim tugas untuk anak pada pagi hari misalnya mengirim tugas pada hari senin kemudian mengirim kembali tugas yang sudah dikerjakan pada hari selasa jadi saya ada waktu mendampingi anak saya belajar pada malam hari. Saya juga sangat berterima kasih pada ibu guru semuanya karena telah membantu saya mengajar anak saya di rumah. ${ }^{9}$

Proses pembelajaran daring ini bukan hanya guru dan anak yang berperan aktif akan tetapi peran orang tua juga sangat penting apalagi menggunakan android dan juga agar anak tidak tertinggal pembelajaran dan memahami apa yang disampaikan oleh guru. Pelaksanaan kegitan pembelajaran daring ini lebih kepada praktek yang di rekam dalam sebuah video. Video yang dikirimkan oleh guru berupa rekaman visual guru yang memberikan motivasi kepada anak dan orang tua agar orang tua selalu menjadi pendamping dalam pembelajaran daring. Untuk menunjang kegiatan pembelajaran guru telah membuat group whatsapp untuk mengerjakan dan menginformasikan tugas atau tema-tema yang dipelajari dari guru. Menjelaskan tentang kegiatan yang dilaksanakan sebagai panduan oleh orang tua selama kegiatan belajar dengan anak. Proses pembelajaran berbasis daring ini sangat penting melibatkan orang tua yang selalu memberikan dukungan, mendampingi dan membantu anak dalam menyelesaikan tugas yang diberikan dari sekolah.

${ }^{8}$ Mas'ulun, Selaku Kepala TK Satap Inpres 1 Baluase "Hasil Wawancara" di Rumah Ibu Mas'ulun, Pada Tanggal 04 Mei 2021

'Andia, Selaku Orang Tua Anak Didik TK Satap Inpres 1 Baluase "Hasil Wawancara" di Rumah Ibu Andia, Pada Tanggal 06 Mei 2021 


\section{B. Peran Orang Tua dan Guru dalam Proses Pembelajaran Daring}

Orang tua mempunyai peran yang sangat penting dalam pendidikan anak terutama dalam proses pembelajaran orang tua harus mendampingi anak apalagi pada masa sekarang ini yang mengharuskan anak untuk belajar di rumah. Orang tua sangat berkewajiban untuk memberikan motivasi dan dukungan agar anak tetap semangat belajar di rumah agar anak dapat mengikuti pembelajaran dengan baik dan efektif dengan adanya pendampingan dari orang tua.

Orang tua juga berperan untuk mendampingi anak agar tetap senang dan nyaman mengikuti pembelajaran daring saat di rumah. Sebab, banyak anak yang ingin kembali sekolah dan merasa bosan dengan pelaksanaa pembelajaran daring. Hal ini sejalan dengan penuturan dari ibu Fatmin orang tua dari anak didik TK Satap Inpres 1 Baluase, pada saat sesi wawancara sebagai berikut:

Memang orang tua sangat berperan penting terhadap pendidikan anak nya apalagi sistem pembelajaran seperti saat ini yaitu melakukan pembelajaran daring yang dimana bukan hanya guru dan anak yang aktif dalam pembelajaran akan tetapi orang tua juga sangat berperan penting dalam mendampingi anak saat belajar di rumah. Dan saya meningkatkan pembelajaran pada anak saya dalam membantu guru di sekolah untuk melangsungkan pembelajaran anak saya yaitu dengan membantu anak belajar pada saat diberikan tugas dari guru kelas. $^{10}$

Hal ini juga sejalan dengan penuturan dari ibu Haya orang tua dari Refan anak didik di TK Satap Inpres 1 Baluase, sebagai berikut:

Saya mengajar anak saya di waktu malam hari sebelum tidur pukul 19:0020:00 maksimal satu jam karena rutinitas saya pada waktu siang. Saya menyempatkan waktu untuk mengajar anak saya pada saat mengerjakan tugas yang diberikan oleh guru di sekolah. ${ }^{11}$

Dari penjelasan ibu Haya orang tua anak didik TK Satap Inpres 1 Baluase, bahwa kesempatan orang tua hanya ada pada malam hari untuk membantu anak belajar mengejarkan tugasnya yang diberikan oleh guru di sekolah karena pekerjaan orang tua hanya sebagai petani kebun untuk kebutuhan hidup sehari-hari.

Selain orang tua, guru juga sangat berperan penting dalam melakukan upaya tertentu agar pembelajaran daring dapat bermanfaat dan tentunya menyenangkan, guru juga harus menciptakan suasana belajar jadi lebih menyenangkan bagi anak didik agar anak tidak mudah bosan. Pembelajaran daring dapat berjalan dengan

\footnotetext{
${ }^{10}$ Fatmin, Orang Tua Anak Didik TK Satap Inpres 1 Baluase "Hasil Wawancara" di Rumah Ibu Fatmin, Pada Tanggal 10 Mei 2021

${ }^{11}$ Haya, Orang Tua Anak Didik TK Satap Inpres 1 Baluase "Hasil Wawancara" di Rumah Ibu Haya, Pada Tanggal 25 Mei 2021
} 
lancar, bermakna, serta tercapai hasil belajar yang baik harus didukung oleh kemampuan guru terhadap penguasaan komputer dan internet.

Guru yang memiliki kinerja yang baik, akan mampu menyampaikan pelajaran

yang baik dan bermakna, mampu memotivasi anak didik, terampil dalam memanfaatkan media, mampu membimbing dan mengarahkan anak didikdalam pembelajaran sehingga anak didik akan memiliki semangat dalam belajar, senang dalam proses pembelajaran dan merasa mudah memahami materi pembelajaran yang disampaikan oleh guru. Pada proses pelaksanaan pembelajaran tentunya perlu untuk guru memberikan motivasi kepada anak didik. Dengan adanya moivasi dari guru maka akan menumbuhkan rasa percaya diri pada diri anak didik untuk terus berlatih dan berkembang menjadi lebih baik. Peran seorang guru sebagai motivator dalam proses belajar merupakan salah satu aspek yang paling penting.

\section{Kendala dan Solusi Dalam Proses Pembelajaran Daring di TK Satap Inpres 1 Baluase}

Kendala berarti halangan, rintangan, faktor atau keadaan yang membatasi, menghalangi, atau mencegah pencapaian sasaran, kekuatan yang memaksa pembatalan pelaksanaan. Kendala dalam pembelajaran merupakan beberapa hambatan yang menghambat jalannya pembelajaran yang dilihat dari faktor manusiawi baik dari faktor guru, orang tua, anak didik, dan fasilitas. Setiap masalah pasti ada solusi yang bisa membantu dalam menyelesaikan permasalahan tersebut. Dalam pembelajaran daring selama pandemi covid-19, banyak kendala yang dihadapi guru sebagai pendidik dan pengajar.

Bukan hanya guru saja orang tua dan anak didik juga mengalami kendala dalam pelaksanaan pembelajaran selama masa pandemi ini. Pembelajaran yang semula tatap muka (luring) akibat pandemi tersebut berubah dengan banyak dilakukan secara online (daring). Berikut ini kendala dan solusi dalam proses pembelajaran daring diantaranya sebagai berikut:

1. Kendala yang dialami orang tua

Proses pembelajaran yang dilakukan di rumah menjadi hal yang sangat baik, karena anak menjadi lebih dekat dengan orang tua. Pembelajaran daring memaksa orang tua untuk dapat menggunakan teknologi karena orang tua akan mengajarkan teknologi tersebut kepada anaknya. Namun ada saja kendala yang dihadapi orang tua dalam proses pembelajaran daring saat ini.

Penerapan pembelajaran berbasis daring yang diterapkan di TK Satap Inpres 1 Baluase, membuat orang tua harus mengikuti sistem pembelajaran yang diterapkan di sekolah tersebut meskipun keadaan sinyal yang terkadang susah. Berikut penuturan dari ibu Haya orang tua anak didik:

Kendala yang sering terjadi itu sinyal yang terkadang susah yang membuat saya kadang terlambat dalam mengirim tugas anak saya kepada guru kelas. 
Terkadang saya juga harus mencari sinyal internet yang bagus kalau sinyalnya tetap tidak baik maka saya menunggu sampai sinyalnya membaik karena sinyal nya kadang susah kadang mudah. ${ }^{12}$

Pernyataan ibu Haya orang tua anak didik TK Satap Inpres 1 Baluase, bahwa susahnya jaringan internet yang menghambat orang tua untuk mengirimkan tugas anak kepada guru menjadi tidak tepat waktu karena jaringan internet yang terkadang susah dan terkadang mudah. Dengan adanya pembelajaran daring pengeluaran orang tua menjadi bertambah yaitu membelikan kuota internet untuk dapat melakukan pembelajaran daring. Hal ini yang selalu menjadi kendala dalam pembelajaran daring karena keadaan ekonomi orang tua anak didik yang berbeda-beda. Berikut penuturan dari ibu Fatmin orang tua anak didik TK Satap Inpres 1 Baluase, sebagai berikut:

Salah satu kendala saya itu kuota yang terlalu mahal namun karena pembelajaran daring ini dilaksanakan seminggu sekali jadi hal itu sangat meringankan saya untuk mengefektifkan pembelajaran daring dan menghemat kuota internet. ${ }^{13}$

Penuturan ibu Haya orang tua anak didik TK Satap Inpres 1 Baluase, menggambarkan bahwa kendala yang dialami orang tua yaitu mahalnya kuota internet namun dengan adanya kebijakan dari sekolah maka dapat meringankan beban kuota yang mahal.

2. Kendala yang dialami guru

Selama pandemi covid-19 seluruh kegiatan dilakukan sesara daring termasuk kegiatan belajar mengajar. Pada kegiatan belajar mengajar guru harus siap mengahadapi segala kondisi apapun dan harus tetap menjalankan tugasnya meskipun pembelajaran dilakukan dalam jarak jauh. Dengan adamya proses belajar mengajar daring banyak orang tua yang merasa kesulitan dalam memahami materi yang disampaikan karena dalam kondisi seperti ini orang tua menjadi sumber materi utama bagi anak didik. Pada penerapan pembelajaran berbasis daring yang diterapkan di TK Satap Inpres 1 Baluase, yang dimana setiap pemahaman orang tua dalam menanggapi tugas atau materi yang diberikan oleh guru berbeda-beda. Sehingga guru menjelaskan kembali materi yang sudah diberikan. Berikut ini penuturan dari guru TK Satap Inpres 1 Baluase mengenai hal ini:

\footnotetext{
${ }^{12}$ Haya, Orang Tua Anak Didik TK Satap Inpres 1 Baluase, "Hasil Wawancara" di Rumah Orang Tua Anak Didik, Pada Tanggal 25 Mei 2021

${ }^{13}$ Fatmin, Orang Tua Anak Didik TK Satap Inpres 1 Baluase, "Hasil Wawancara" di Rumah Orang Tua Anak Didik, Pada tanggal 10 Mei 2021
} 
Yang kami alami dalam kegiatan pembelajaran yaitu ada beberapa orang tua yang kurang memahami tugas yang diberikan oleh guru sehingga harus mengulang kembali penjelasannya dengan menggunakan sesi tanya jawab di whatsapp group untuk mempermudah suatu pembelajaran. ${ }^{14}$

Dari penuturan ibu Ufariah guru di TK Satap Inpres 1 Baluase, bahwa mereka menggunakan whatsapp group untuk melakukan pembelajaran untuk mempermudah orang tua dan anak didik memahami apa yang diberikan oleh guru.

Selama pandemi ini kegiatan belajar mengajar disesuaikan dengan waktu luang orang tua anak didik karena tidak semua orang dapat mendampingi anak didik dalam belajar di rumah. Pada pembelajaran berbasis daring yang diterapkan di TK Satap Inpres 1 Baluase, yang dimana beberapa anak didik kurang efektif dalam mengikuti pembelajaran dikarenakan orang tua anak didik yang sibuk. Sehingga menghambat anak didik dalam mengikuti pembelajaran. Berikut ini penuturan dari guru TK Satap Inpres 1 Baluase mengenai hal ini:

Salah satu kendala yang kami alami dalam pembelajaran daring ini yaitu ada beberapa anak didik yang tidak efektif mengikuti pembelajaran karena orang tua yang tidak selalu bisa mendampingi anak belajar karena sibuk bekerja sehingga pembelajaran daring ini dilaksanakan seminggu sekali agar orang tua bisa meluangkan waktu untuk membantu anak belajar di rumah. ${ }^{15}$

Pernyataan dari ibu Azlimah guru TK Satap Inpres 1 Baluase, bahwa ada sebagian orang tua anak didik yang tidak selalu bisa mendampingi anak belajar sehingga menghambat proses pembelajaran.

3. Solusi

Solusi adalah suatu proses pembelajaran yang dimana kita berusaha untuk memperbaik diri dari praktek yang kita lakukan sehari-hari. Solusi juga merupakan cara atau jalan keluar yang digunakan untuk memecahkan atau menyelesaikan suatu masalah tanpa adanya tekanan. Seperti saat kita melakukan dengan metode ilmiah, kita merumuskan masalah dan membuat hipotesis, kesimpulan itu adalah solusinya, tanpa tekanan artinya kita menuruti kaidahkaidah yang ada dan bukan hanya dari argumen kita sendiri.

Dalam mengatasi permasalahan orang tua anak didik yang dimana kendala sinyal internet yang terkadang susah dan kuota internet yang mahal, terdapat solusi yang bisa dilakukan untuk mengatasinya yaitu dengan cara guru melaksanakan pembelajaran seminggu sekali agar dapat meringankan orang tua

\footnotetext{
${ }^{14}$ Ufariah, Guru di TK Satap Inpres 1 Baluase, "Hasil Wawancara” di Sekolah TK Satap Inpres 1 Baluase, Pada Tanggal 04 Mei 2021

${ }^{15}$ Azlimah, Guru di TK Satap Inpres 1 Baluase "Hasil Wawancara” di Sekolah TK Satap Inpres 1 Baluase, Pada Tanggal 24 Mei 2021
} 
anak didik. Hal ini didukung dengan penuturan guru TK Satap Inpres 1 Baluase sebagai berikut:

Ada sebagian tempat tinggal orang tua anak didik mengalami kesulitan mendapat sinyal internet jadi kami melaksanakan sistem pembelajaran daring ini seminggu sekali akan tetapi mencakup semua aspek pembelajaran dalam satu minggu itu sehingga anak didik bisa menyelesaikan tugas yang diberikan. ${ }^{16}$

Langkah yang diambil ini cukup efektif dalam membantu anak didik agar tidak tertinggal pembelajaran. Selain itu, untuk permasalahan kurangnya pemahaman orang tua terhadap tugas atau pembelajaran yang diberikan oleh guru dan orang tua yang sibuk bekerja sehingga orang tua tidak selalu mendampingi anak belajar. Dari hasil wawancara masing-masing memiliki solusi sebagaimana yang dituturkan oleh kedua narasumber. Berikut terdapat pernyataan dari ibu Ufariah dan ibu Azlimah bahwa:

Untuk orang tua anak didik yang kurang paham dengan tugas yang diberikan maka kami melakukan sesi tanya jawab di whatsapp group sehingga orang tua anak didik yang kurang paham bisa kami jelaskan kembali maksud dari tugas yang telah diberikan. ${ }^{17}$

Setiap permasalahan pasti ada solusinya begitupun yang dialami oleh guru TK Satap Inpres 1 Baluase, dalam mengatasi masalah ini guru memiliki cara agar anak tetap mengikuti pembelajaran dan mengerjakan tugas yang diberikan oleh guru tentu dengan bantuan orang tua maka dari itu guru memberikan kebijakan pada orang tua untuk membantu anak belajar pada malam hari agar rutinitas orang tua anak didik tidak terganggu.

\section{KESIMPULAN}

Berdasarkan hasil penelitian dan pembahasan yang termuat dalam pembahasan sebelumnya tentang peran orang tua dan guru terhadap anak pada pembelajaran daring dapat disimpulkan,sebagai berikut:

1. Proses pembelajaran berbasis daring di TK Satap Inpres 1 Baluase pada masa pandemi covid-19 dilaksanakan seminggu sekali akan tetapi mencakup semua aspek pembelajaran menggunakan aplikasi whatsapp yang dimana proses pembelajarannya guru menggunakan rekaman video untuk memberikan tugas kepada anak didik kemudian dikirim kepada orang tua anak didik. Orang tua

\footnotetext{
${ }^{16}$ Fitriani, Guru di TK Satap Inpres 1 Baluase "Hasil Wawancara” di Sekolah TK Satap Inpres 1 Baluase, Pada Tanggal 31 Mei 2021

${ }^{17}$ Ufariah, Guru Kelas di TK Satap Inpres 1 Baluase "Hasil Wawancara” di Sekolah TK Satap Inpres 1 Baluase, Pada Tanggal 04 Mei 2021
} 
juga berperan untuk mendampingi anak agar tetap senang dan nyaman mengikuti pembelajaran daring saat di rumah. Sebab, banyak anak yang ingin kembali sekolah dan merasa bosan dengan pelaksanaa pembelajaran daring.

2. Kendala dan solusi selama pembelajaran berbasis daring pada masa pandemi covid-19 di TK Satap Inpres 1 Baluase sebagai berikut: (1) Jaringan internet yang susah, (2) Kuota internet yang susah, (3) Kurangnya pemahaman orang tua terhadap pembelajaran, (4) Orang tua anak didik yang sibuk. Adapun solusinya sebagai berikut: (1) Melaksanakan pembelajaran daring seminggu sekali, (2) Melakukan sesi tanya jawab di whatsapp group.

\section{SARAN}

Berdasarkan hasil penelitian yang telah dilakukan, yaitu tentang peran orang tua dan guru terhadap anak pada pembelajaran daring, maka penulis mengemukakan beberapa saran sebagai berikut:

1. Bagi guru, diharapkan agar bisa lebih efektif lagi dalam melaksanakan pembelajaran berbasis daring dan tetap menjaga komunikasi dengan baik pada orang tua anak didik agar dapat bekerjasama sehingga pembelajaran jadi lebih efektif.

2. Bagi orang tua, diharapkan untuk meluangkan lebih banyak waktu untuk mendampingi anak selama belajar daring di rumah.

\section{DAFTAR PUSTAKA}

Bagus, Ida dan Surya, Benny. Adaptasi di Masa Pandemi, Cet.1; Bandung; Nilacakra; 2020.

Fahrina Afrillia dan Amelia, Karla. dkk, Peran Guru dan Keberlangsungan Pembelajaran di Masa Pandemi Covid-19, Cet.1; Aceh; Syiah Kuala University Press, 2020.

Lutfi, Andi Muhammad dan Arianto, Akhmad dkk, Media Daring (Online) Solusi Pembelajaran Jarak Jauh, Cet.1; Parepare; IAIN Parepare Nusantara Press, 2020.

Moleong, Lexy J. Metodologi Penelitian Kualitatif, Bandung: Remaja Rosdakarya, 2007.

Sudarsana, I Ketut. dkk, COVID-19: Perspektif Pendidikan, Cet.1; Denpasar; Yayasan Kita Menulis, 2020.

Sugiyono, Metode Penelitian Pendidikan Pendekatan Kuantitaf, Kualitatif Dan $R \& D$ Cet.XX;Bandung: Alfabet, 2014. 